Jurnal Bimbingan Konseling
$10(2)(2021): 142-147$
UNNES

\title{
The Effect of Self-Compassion and Islamic Spiritual Orientation on Academic Anxiety
}

\author{
Fuja Septia Ningrum ${ }^{\bowtie}$, Edy Purwanto, Mulawarman Mulawarman
}

Universitas Negeri Semarang, Indonesia

\begin{tabular}{|c|c|}
\hline Article Info & Abstract \\
\hline $\begin{array}{l}\text { History Articles } \\
\text { Received: } \\
15 \text { May } 2021 \\
\text { Accepted: } \\
\text { 20 Juny } 2021 \\
\text { Published: } \\
30 \text { August } 2021\end{array}$ & $\begin{array}{l}\text { High anxiety level which can disrupt students' concentration and reduce their } \\
\text { memory performance results in less focus, confusion, and less optimal learning } \\
\text { in terms of comprehending subject materials. Thus, this study attempted to } \\
\text { analyze the effects of self-compassion and Islamic spiritual orientation on } \\
\text { academic anxiety. It involved students from four public schools in Semarang as } \\
\text { population. Further, they were sampled using cluster random sampling } \\
\text { technique and resulted } 350 \text { students. After some analyses were carried out, it }\end{array}$ \\
\hline $\begin{array}{l}\text { Keywords: } \\
\text { academic anxiety, } \\
\text { Islamic spiritual } \\
\text { orientation, self- }\end{array}$ & $\begin{array}{l}\text { was known that there was a negative and significant effect of self-compassion } \\
\text { and Islamic spiritual orientation on students' academic anxiety, while self- } \\
\text { compassion and Islamic spiritual orientation on academic anxiety reduction } \\
\text { can be understood through changes in positive self-perception }\end{array}$ \\
\hline
\end{tabular}

compassion

Correspondence address:
J1. Bhayangkara No 24 Talang Rimbo Lama Curup Tengah,
Bengkulu, Indonesia
E-mail: Fuja.Septia0011@gmail.com 


\section{INTRODUCTION}

Academic anxiety can motivate an individual to gain better academic achievement. According to Shakir (2014) academic anxiety significantly motivate students to study harder and get more achievement. However, at high level, this anxiety can disrupt concentration and memory. Students who have academic anxiety will attempt to achieve what they desire, but along with the anxiety they may feel unsure of their ability so that in receiving materials being taught, students become not focused, confusing, and less optimal.

Surely, academic anxiety turns into an issue that can drive academic dishonesty during exams. It happens because students are anxious about failure in learning. Other things influencing this state are tests, score competition, deadline, teacher, classroom environment, career, and the future (Bariyyah, 2012).

A lot of students experience anxiety when doing difficult academic tasks, especially those who have low learning ability. Dobson (2012) mentions academic anxiety can be unbeneficial. As a student with low academic achievement, academic anxiety will surely affect their responses to additional academic tasks. Based on Firmantyo \& Asmadi (2016), high academic anxiety will reduce learning motivation.

Self-compassion is a whole selfacceptance that as a human, it is normal to make mistakes, but there is no need to regret the mistakes excessively. Neff (2003) states selfcompassion can be seen when one has selfperspective to care, not judge, and give understanding and goodness to himself when experiencing failure or making mistakes, but all these matters are not supposed to be done harshly.

Individuals who lack of self-compassion tend to focus on negative things within themselves, surrounding environment, blame for the non-ideal life, curse themselves for all failures and helplessness about something which then result in hating themselves, treating themselves rudely and badly. McEwan, Elander, \& Gilbert (2018) argue that any intervention applied to self-compassion will effectively reduce anxiety, stress, and depression. Through the improvement of self-compassion, someone will get improvement on self-efficacy, reduce selfcritics, anxiety, stress, and anxiety during examinations compared to similar test takers with high anxiety so that at the end he can improve academic mastery goal orientation.

Another thing which affects academic anxiety is religiosity. A study by Uktia, Iredho, \& Zaharuddin (2016) shows that religiosity has a contribution to academic anxiety indicated by the negative and significant relationship between religiosity and academic anxiety found in students of Islamic Senior High School (MAN) in one of cities in Palembang. Thus, the higher students' religiosity, the lower academic anxiety they will feel.

This study attempted to analyze the effects of self-compassion and Islamic spiritual orientation on academic anxiety with hope that it can enrich and develop knowledge about guidance and counseling in terms of selfcompassion, Islamic spiritual orientation, and academic anxiety.

\section{METHODS}

The population in this study was four Public Senior High Schools (SMA Negeri) in Semarang City. Cluster random sampling was used to sample 350 Tenth Grade students in South Semarang and Central Semarang subdistricts.

In terms of variables, there were 5 choices in form of likert scale to measure selfcompassion variable covering 26 aspects of selfkindness, common humanity, mindfulness and isolation, self-judgement, and over-identified. This scale had the item correlation ranged from 0.52-0.94 and alpha coefficient of 0.96 .

Another variable, Islamic spiritual orientation was measured using 5 choices of likert scale covering 20 items with the aspects of belief in Allah, life purposes which are blessed by Allah, and awareness of difficulty. This scale 
had item correlation ranged from $0.38-0.91$ and alpha coefficient of 0.86 .

Academic anxiety variable was assessed using 5 choices of likert scale for 16 items with the aspects of academic expectation, work load and test, and students' academic self-perception. This scale gained item correlation between 0.52 0.84 and alpha coefficient of 0.93 .

Self-compassion scale was adapted from Neff, namely Self-Compassion Scale (SCS), Islamic spiritual orientation was designed by the researchers themselves, and academic anxiety was adapted from the Perception of Academic Stress (PAS) by Bedewy \& Adel. All adaptation was done based on the procedures proposed by
Beaton, Bombardier, Guillemin, \& Ferraz (2000).

\section{RESULTS AND DISCUSSION}

The data of academic anxiety, selfcompassion, and Islamic spiritual orientation in all schools are presented in table 1. Based on the results of descriptive statistic analysis, the mean of academic anxiety was 73.5 with standard deviation of 5.10 , the mean and standard deviation of self-compassion was 86.3 and 6.45 respectively, and Islamic spiritual orientation mean and standard deviation was 69.7 and 2.46 respectively.

Table 1. The Effect of Self-Compassion and Islamic Spiritual Orientation on Academic Anxiety

\begin{tabular}{lccc}
\hline Variable & $\mathrm{N}$ & Mean & Standard Deviation \\
& & & \\
\hline Academic Anxiety & 350 & 73.5 & 5.10 \\
Self-compassion & & & \\
Islamic Spiritual Orientation & 350 & 86.3 & 6.45 \\
& 350 & 69.7 & 2.46 \\
\hline
\end{tabular}

Table 2. The Results of Multiple Linear Regression Test of the Effect of Self-Compassion and Islamic Spiritual Orientation on Academic Anxiety

\begin{tabular}{|c|c|c|c|c|c|}
\hline Prediktor & $\mathrm{R}$ & $\mathrm{R}^{2}$ & $\mathrm{~F}(3,03)$ & $\beta$ & $\mathrm{t}$ \\
\hline Kriteria: academic anxiety & .26 & .07 & $13.55 * * *$ & & \\
\hline $\begin{array}{l}\text { Self } \\
\text { Compassion }\end{array}$ & & & & -.11 & $-2.90^{* *}$ \\
\hline Islamic Spiritual Orientatior & & & & -.42 & $-3.97 * * *$ \\
\hline
\end{tabular}

Based on table 2, self-compassion and Islamic spiritual orientation negatively predicted academic anxiety (self-compassion: $\beta=-0,11$, $p<0.01$, Islamic spiritual orientation: $\beta=-0,42$, $\mathrm{p}<0.01)$. Both variables explained the variance of academic anxiety by $7.2 \%$, meaning that there was a significant effect between self-compassion and Islamic spiritual orientation on the academic anxiety of the students in SMA Negeri in Semarang City.

The findings of this study are relevant to a study by Chairunnisa \& Fourianalistyawati (2019) that someone who has negative emotions to himself actually needs social and psychological support. Both self-compassion and Islamic spiritual orientation are forms of psychological support coming from within that can reduce negative emotion, and even bring the positive one. In details, the internal support to bring this positive emotion consists of coping strategies, resilience, personal traits, self-esteem, self-compassion, and spirituality. In addition, a study by Akin \& Akin (2017) examined the predictive role of self-compassion on spiritual experience. It shows that self-compassion is able to improve spiritual experience and beneficial to counter self-critical tendency. Moreover, Muris, et al, (2016) revealed adolescents' negative 
correlation regarding self-compassion, anxiety, and depression on religion and spiritual orientation. Next, Dehghani \& Vida (2017) argue that students with high spiritual orientation tend to have a high level of resignation and acceptance. This is relevant to a study by (Moritz, Kelly, Xu, Toews, \& Rickhi, 2011) that students experience a decrease in depression and anxiety in academics after getting extra hours of class. Further, Toosi et al (2017) conclude that spirituality is positively and significantly related to religious orientation along with increasing levels of education, emotional, and spiritual intelligence. Amrai et al (2011) confirm a close relationship between religious orientation with anxiety and depression in students, namely the increase in students' religious orientation will reduce their students depression and anxiety.

Marwing (2019) explains that Islamic spiritual orientation can emerge more positive and optimistic thoughts and feelings as well as calmness. Dumont \& Provost (1999) argues selfcompassion and spiritual orientation can develop personal perception to be positive and strong. By having the ability to control selfperception, someone can manage their negative emotion, such as anxiety, depression, and daily stress in every day life. Self-compassion and spiritual orientation can establish positive and strong impression for individuals and those make the individuals have a capacity to deal with daily life aspects. Yari \& Tahereh (2012) reveal individuals with positive perception of their ability will feel confident in difficult situations and be able to cope with anxiety and solve it.

The findings of this study enrich the knowledge about guidance and counseling in terms of knowing self-potential and any components within students. Guidance and counseling takes part in the development of individual by providing services in the field of personality and social. At the same time, it helps students know the importance of understanding academic anxiety towards fear and excessive worries about learning process.

\section{CONCLUSION}

Based on the findings, it can be concluded that there are some effects found in selfcompassion and Islamic spiritual orientation on students' academic anxiety. It was also confirmed that self-compassion and Islamic spiritual orientation play roles in developing selfperceptions. That is why the higher selfcompassion and Islamic spiritual orientation, the more positive self-perception will be.

The findings of this study can be used as literature in understanding problems regarding academic anxiety on self-compassion and Islamic spiritual orientation so that students can be more confident by applying Islamic teachings in daily life and motivate themselves to improve academic achievement both personally and socially. Similar future studies are suggested to make use of these findings in providing understanding about academic anxiety, such as fear, stress, and decreased learning achievement.

\section{REFRENCES}

Akin, A., \& Akin, U. (2017). Does SelfCompassion Predict Spiritual Experiences of Turkish University Students? Journal of Religion and Health, 56(1), 109-117. https://doi.org/10.1007/s10943-0150138-y

Amrai, K., Hamzeh, A, Z, Fariborz, S, A \& Maryam, S, S. (2011). The relationship between the religious orientation and anxiety and depression of students. Procedia Social and Behavioral Sciences, 15 , 613-616 https://doi.org/10.1016/j.sbspro.2011.03 .150

Bariyyah, K. (2012). Stres akademik. Diunduh dari http://konselingkita.com.

Bedewy, D and Adel, G. (2015). Examining perceptions of academic stress and its sources among university students: The Perception of Academic Stress Scale. Health Psychology Open: 1-9. https://doi.org/10.1177/2055102915596 714 
Beaton, D. E., Bombardier, C., Guillemin, F., \& Ferraz, M. B. (2000). Guidelines for the process of cross-cultural adaptation of self-report measures. Spine, 25(24), 31863191

Chairunnisa, A., \& Fourianalistyawati, E. (2019). Peran Self-Compassion Dan Spiritualitas Terhadap Depresi Pada Ibu Hamil. Jurnal Psikologi Ulayat, 6, 14-36. https://doi.org/10.24854/jpu02019-131

Dehghani, F., \& Vida, A. (2017). The Relationship of Religious Orientation and Spiritual Health to Resilience among High School Sophomores in Kerman. Research On Religion And Health. 3(4), 66-67.

https://journals.sbmu.ac.ir/jrrh/article/v iew/15488/13555.

Dumont, M., \& Provost, M. A. (1999). Resilience in Adolescents: Protective Role of Social Support, Coping Strategies, SelfEsteem, and Social Activities on Experience of Stress and Depression. Journal of Youth and Adolescence, 28(3), 343-363.

Dobson, C. (2012). Effects of Academic Anxiety on the Performance of Students with and Without Learning Disablities and How Students can Cope with Anxiety at School. Northern Michigan University, Marquette. https://www.nmu.edu -> Dobson_Cassie_MP.pdf

Firmantyo T., \& Asmadi A. (2016). Integritas Akademik dan Kecemasan Akademik dalam Menghadapi Ujian Nasional pada Siswa. Psikohumaniora: Penelitian Psikologi. 1(1), 1-11. https://doi.org/10.21580/pjpp. v1i1.959.

Marwing, A. (2019). Efektifitas Terapi Seft (Spiritual Emotional Freedom Technique) Terhadap Penurunan Agresifitas Remaja Warga Binaan Lembaga Pembinaan Khusus Anak (LPKA). Psikoislamika: Jurnal Psikologi Dan Psikologi Islam, 16(1), https://doi.org/10.18860/psi.v16i1.7510

Muris, P., Meesters, C., Pierik, A., \& Kock, B. De. (2015). Good for the Self: Self-
Compassion and Other Self-Related Constructs in Relation to Symptoms of Anxiety and Depression in Non-clinical Youths. Journal of Child and Family Studies. https://doi.org/10.1007/s10826015-0235-2

McEwan, K., Elander, J. \& Gilbert, P. (2018). Evaluation of a web-based selfcompassion intervention to reduce student assessment anxiety. Interdisciplinary Education and Psychology. 2(1), 6, pp. 1-24. http://hdl.handle.net/10545/622811

Moritz, S., Kelly, M. T., Xu, T. J., Toews, J., \& Rickhi, B. (2011). A spirituality teaching program for depression: Qualitative findings on cognitive and emotional change. Complementary Therapies in Medicine, 19(4), 201-207. https://doi.org/10.1016/j.ctim.2011.05.0 06

Neff, K. D. (2003). The development and validation of a scale to measure selfcompassion. Self and Identity, 2, 223-250. doi: 10.1080/15298860390209035

Shakir, M. (2014). Academic Anxiety as a Correlate of Academic Achievement. Journal of Education and Practice, 5(10),29-37.

https://www.iiste.org/Journals/index.ph p/JEP/article/view/12335/12665

Toosi S, A, D, Seyyed A, D; Emadian, ......\& Maryam S. (2017). Relationship between Different Types of Educational, Emotional and Spiritual Intelligence and Second Grade High School Female Students' Religious Orientation, in Sari, Iran. International Journal of Education \& Literacy Studies. http://dx.doi.org/10.7575/aiac.ijels.v.5n .4 p. 116

Uktia, F., \& Fani, I. (2016). Hubungan Antara Religiusitas Dengan Kecemasan Akademik Pada Ssiswa Madrasah Aliyah Negeri. PSIKIS-Jurnal Psikologi Islami. 2 (2) 149-160. http://jurnal.radenfatah.ac.id/index.php /psikis/article/view/1186 
Yari, Somaie \& Tahereh G, B. (2012). The Relationship Between Self-Efficacy and Self Persception with Anxiety of Examination in High School Students.
International Journal on New Trends in Education and Their Implications.3(4). www.ijonte.org. 